\title{
The Enablers and Outcomes of Research Productivity among Junior High School Mathematics Teachers: A Structural Model
}

\author{
Roldan Soriano Cardona ${ }^{1 *}$ \\ ${ }^{1}$ Philippine Normal University-North Luzon, PHILIPPINES
}

Received 3 October 2019 - Accepted 15 August 2020

\begin{abstract}
Research is a universally acknowledged tool in and for education. This study investigates the enablers and outcomes of research productivity of high school mathematics teachers. Using partial least square structural equation modelling, data from 211 tenth-grade mathematics teachers of five public schools divisions in the northeastern part of Philippines was evaluated. Findings showed that the research participation and productivity respondents was generally low but the teacher-researchers' growth potential is immense. The individual-institutional-leadership model strongly and positively influenced research productivity. Leadership in research in the school level is a critical area towards research productivity. The findings have policy implications in terms on how to encourage mathematics teachers to participate in research-related activities that will contribute to a research-informed teaching and learning. It is highly recommended to develop interventions to improve involvement, extrinsic motivation, mentoring, networking, resources, and leadership domains.
\end{abstract}

Keywords: mathematics teachers, mathematics teaching-learning, productivity, research involvement, structural equation modelling

\section{INTRODUCTION}

Math educators play a vital role in building and in refining of knowledge towards the improvement of the $\mathrm{K}$ to 12 mathematics curriculum delivery in the Philippines. Their sphere of duty extends not only as facilitators of learning but also as evidence-based practitioners (Santo, Engstrom, Reetz, Schweinle, \& Reed, 2009). As research-informed professionals, they are expected to be equipped with an evolving perspective on the theory and practices of teaching and learning which engage them beyond content (Chapman, 2017; Zuljan \& Vogrinc, 2010; Craig, 2009).

Research is extremely important in mathematics education (Segal, 2009). It forms the basis of the content of teaching (Marsh \& Hattie, 2002; Thomas \& Harris, 2001). The experiences math teachers generate from participating in researcher-related activities are spilled over and instilled in students through the teaching activities (Demski \& Zimmerman, 2000). Active researchers who are aware of the newest perspectives in their field (Feamster, 2013) becomes the first channel through which students clarify, update, and amend the teaching of a topic (uz Zaman, 2004). Thus, integrating research in teaching can result to growth in teaching efficacies, increased self-awareness, improved problemsolving skills, enhanced autonomous learning (Cabaroglu, 2014; Prince, Felder, \& Brent, 2007), with broader questioning and reflection skills (Adler, 1997). Magidson (2005) exclaimed the changes her own research brought in her teaching like the deepened understanding of the learning process, sensitivity to language, making fewer and assumptions in the classroom. Conducting research helps one engage in a focused study of their own practice and builds confidence in teachers as professionals (Segal, 2009). Additionally, successful teacher-researchers can increase confidence and credibility leading to a better and effective teaching performance (Thomas \& Harris, 2001).

In the case of the Philippine Basic Educational System, Republic Act (RA) 9155 or the Governance of Basic Education Act of 2001 stipulates in Chapter 1 the accountability and responsibility undertaking national educational research studies from which it can become

(c) $\mathbf{2 0 2 0}$ by the authors; licensee Modestum. This article is an open access article distributed under the terms and conditions of the Creative Commons Attribution License (http://creativecommons.org/licenses/by/4.0/). 


\section{Contribution to the literature}

- The concept of teacher-researcher is still murky in the sector of basic education. Hence, the paper helps further the body of knowledge about the subject.

- The paper helps assess and evaluate the extent of implementation of the action research thrusts of the basic education sector in the Philippines towards better classroom decisions.

- The study provides a structural model that can become a basis of policy development process.

part of the basis for necessary reforms and policy outputs.

The second key result area (KRA) of the Basic Education Sector Research Agenda (BESRA) mandates teachers to enhance their contribution to learning outcomes by coming up with informed decisions through action or applied researches. Action research is regarded as the convergence between theory and praxis (Afify, 2008) that transforms teacher attitude and approach to instruction (Bonner, 2006), pushes for personal theorizing (Chant, Heafner, \& Bennet, 2004), and ultimately, brings about change (Afify, 2008; Evitts, 2004). The mandate is strengthened with the creation of Basic Education Sector Reform Agenda (BESRA), Policy Development Process (PDP), Research Management Guidelines (RMG), and the provision for Basic Education Research Fund (BERF) through DepEd Order (DO) Nos. 13 s. 2015, 43 s. 2015, 4 s. 2016, 39 s. 2016, and 16 s. 2017.

Given the importance of research in mathematics education and in basic education in general, exploring the contributing factors towards research productivity (RP) is therefore crucial. In the Philippine basic educational system where teaching-research infusion takes its big leap in the recent years, there is a growing aspiration to understand how research-related activities are accomplished, under what conditions it may be stimulated particularly, how organizational practices, or teacher characteristics influence it (Paul, Vijayaragavan, Singh, Burmal, \& Chahal, 2017; Siegel, Waldman, \& Link, 2003) and how leadership and management regards it in the system (Goodall, McDowell \& Singell, 2014). Existing international models like the ones developed by Dundar and Lewis (1998), Teodorescu (2000), Brocato (2001), Bland, Center, Finstad, Risbey, and Staple (2002), Ju (2010), and Angaiz (2015), which exclusively focused on higher education, have demonstrated mixed results and generally were contextdependent. While no one would argue that these models have reflected the general perspectives on which attributes operate in the research systems, the situation in the country where basic education's research thrusts may be considered distinct is not yet well studied. A great interest of local scholars like of Nuqui and Cruz (2012), Dumbrique and Alon (2013), Revilla and Ladisla (2014), Dangan (2014), Quimbo and Sulambo (2014), Marcial (2015), Tagaro (2015) and Etcuban and associates (2016) was poured in recently on this area of research but these were also confined in the tertiary level. Three studies in the basic education by Valdez and Lapinid (2015), Ulla, Barrera, and Acompanado (2017), and Ulla (2018) were conducted by considering the narratives of small subsets of teachers interpreted from the qualitative lens. Their findings revealed that action researches (ARs) helped the teachers in their professional tasks but they had cited multiple dilemmas they face like limited socialization opportunities, tremendous workload and insufficient time, departmental politics, lack of resources that hamper them to conduct researches. A model which describes the direction towards RP of classroom teachers is thus, aptly needed.

This paper probed the enablers and RP outcomes of mathematics high school teachers. The end goal of this endeavour is to develop a structural model that forwards the context of basic education. Specifically, it had the following objectives:

1) describe the RP outcomes of secondary mathematics teachers;

2) identify the extent of the enablers of RP outcomes and performances of secondary mathematics teachers along individual, institutional, and leadership, and

3) develop a structural model towards RP of secondary mathematics teachers.

\section{Research Productivity}

Defining RP is challenging and complicated because it does not have clear-cut definition and measurement (Tafreshi, Imani, \& Grashlag, 2013; Käpylä, Jääskeläinen, \& Lönnqvist, 2010). RP or the quantity and quality in research-related tasks and outcomes includes faculty's publications, which majority (e.g. Abouchedid \& Abdelnour, 2015; Hesli \& Lee, 2011; McInnis, Ramsden, \& Maconachie, 2014) consider as the most important indicator. It also encompasses funded researches (Paul, et al., 2017), utilization of research results to policy formulation, exposure to research trainings (Angaiz, 2015), dissemination through presentations in research fora (Jalloun, 2010; Santo et al., 2009), research awards received (Zamarripa, 1995), professional services rendered, and other innovative and developmental projects.

Blackburn and Lawrence (1995) proposed environmental response and social knowledge as factors of faculty productivity in research. According to the model of Dundar and Lewis (1998), individual characteristics and institutional and departmental 
characteristics facilitate RP. Meanwhile, Teodorescu (2000) proposed an international model that forwarded individual achievement variables and institutional characteristic variables as the main predictors of RP. Aside from individual characteristics, Brocato (2001) added in his model of RP, psychological and cognitive attributes as follows: (a) knowledge and skills in research; (b) explicit plan for research; (c) research involvement and networking; (d) concurrent research projects; (e) awareness about research expectations required for promotion and tenure; (g) personal motivation; (h) training in research; and (i) socialization in the organization.

The model of Bland et al. (2002) postulated eight individual characteristics, 15 institutional characteristics, and four leadership characteristics as predictors of RP. In 2005, Bland and associates showed the interdependence, interaction, and interplay among individual, institutional, and leadership characteristics as proposed by Bland et al. (2002) at research productive institutions. In 2006, Bland et al. integrated the concepts of communication across these three domains which are the individual faculty members, the structure or environment in which the faculty members find themselves, and the leadership of the organization.

Meanwhile, Ju (2010) built on the frameworks of Bland et al. (2005), Bland, Center, Finstad, Risbey and Staples (2006) and Blackburn and Lawrence (1995) when he proposed that RP is influenced by faculty professional characteristics and the interaction effect of peer support research and administration support to research in what he collectively called mega-environment. Using cognitive motivation theory, Williams (2003) proposed a mediated model of research productivity in which environmental variables are controlled, perceptions of organizational priorities are considered motivational antecedents, and personal interest/abilities are assumed to mediate the relationship between the motivational antecedents and the research productivity of the faculty members. The results from structural equation modelling of Tafreshi et al. (2013) showed that organizational factors had no direct effects on research productivity of the members of a university in Iran while individual factors directly influenced it.

\section{METHOD}

\section{Design}

This descriptive study was aimed to investigate the factors that contribute to the RP outcomes of high school mathematics teachers in the Philippines. It sought to test the proposed model for RP using a variance-based modelling technique.

\section{Participants}

This study considered a total of 262 tenth grade mathematics teachers and was able to derive a response rate of 211 or 80.53 percent. The teachers were teaching at that time in the public school divisions in Isabela province (large division), Santiago City (small division), Cauayan City (small division), Quirino province (medium division), and Batanes island-province (small division). These divisions are located in Cagayan Valley Region, in the northeastern island of Luzon, Philippines. The Isabela province together with the cities of Santiago and Cauayan is regarded as second largest province in the country.

Approximately a hundred of schools consisting of national high schools, provincial high schools, and integrated schools, were involved in the undertaking with a modal and minimum number of one participant per school and a maximum of six per school. The teachers were on average 38 years old. Schools from the private sector and schools from coastal towns of Isabela and other security-stricken areas were not involved in the study.

\section{Instruments}

\section{RP outcomes}

A self-report questionnaire using seven indicators and several sub-indicators were utilized to measure math teachers' RP outcomes. The indicators were based on extant of literature and it include research publications, manuscripts, presentations, research-and mathematics-related trainings, affiliations, awards, and other relevant professional services rendered. Only those activities performed and accomplished from 2015 to 2018 were considered. The researcher developed a scoring mechanism based the importance and relevance of an RP indicator.

The questionnaire was validated by five experts and was analysed using the item and scale-levels content validity index or CVI (Polit \& Beck, 2006) and modified kappa (Polit, Beck, \& Owen, 2007). Results showed that modified kappa were from .76 to 1.00 and item-level CVIs were from .80 to 1.00 . The scale-level CVIs on the other hand, listed between .87 and 1.00. These indices exemplify that the measures of RP is highly valid.

\section{Enablers of RP}

This is a 6-point Likert scale from 1 - strongly disagree to 6 - strongly disagree consisting of 60 items. It underwent two external validations: first, by four experts in psychology and guidance counselling; and second, by eight educational and research experts. In both stages, the content validity index (Polit \& Beck, 2006) and modified kappa (Polit et al., 2007) were calculated as well as the 95 percent confidence interval IntraCorrelation Coefficients (ICC) consistency two-way 
random-effects model (Koo \& Li, 2016). In the first stage, item-level CVIs registered from .75 to 1.00 while the modified kappa was from .67 to 1.00 . The scale-level CVI for intrinsic motivation is .94 and 1.0 for extrinsic motivation. In the second stage, the item-level CVIs incurred from .75 to 1.00 and modified kappa of .72 to 1.00. Scale-level CVIs showed .90 to 1.00. The ICCs of .76 to .96 as well as the $95 \%$ ICC demonstrated a fair to high reliability.

Then, it was piloted to 1297 teacher-respondents in the Luzon archipelago either through online or paperand-pencil method. Using exploratory factor analysis (EFA) with Principal Axis Factoring as extraction procedure and Direct Oblimin as rotational technique, the researcher was able to generate eight factors, with total variance of 72 percent, $\mathrm{KMO}=.981$, Barlett's Test of Sphericity (approx. chi-quare of 103,367.83, df $=2415$ ), $\mathrm{p}$ $<.05$. These enablers were as follows: transformational and participative research leadership (TraParLea, 10 items), internal drive and research rationale research self-efficacy (IntDriRat, 11 items), research goals (ResGoa, 8 items), strategic research leadership (StrLea, 5 items), extrinsic motivation (ExtMot, 5 items), research mentoring (ResMen, 7 items), research involvement, networking, and resources (InvNetRes, 13 items), and work habits and research methodology and results selfefficacy (WorHabMetRes ,11 items). Hence, from the original 76 items, the questionnaire was reduced to 60 reflective indicators. These enablers were divided as individual, institutional, and leadership. Then, a final evaluation of the indicators was conducted.

The instrument used to measure research knowledge was based on the local dissertation study of Dullas (2018) whose respondents were math teachers as well. This consisted of 50-multiple-choice items. This instrument was revalidated and the data collected from 162 teacherrespondents underwent Rasch analysis (Linacre, 2011). The analysis yielded 48 items with unidimensionality coefficient of 1.03 , item reliability of .95 , and infit mean square of .86 to 1.15 and outfit mean square of .77 to 1.50 .

\section{Collection}

Permission letters were sought from the regional office of the Department of Education through the Policy, Programs and Research Division (PPRD) and were endorsed to the Divisions Schools Superintendents. A separate letter was provided to the participants. The instruments were administered in two waves, in two different occasions: in the first stage, the RP Outcomes together with the RP Enabler Questionnaire; and in the second stage, the research knowledge. The data were then encoded, sanitized, and analysed.

\section{Analysis}

Descriptive statistics was utilized in the first two objectives while the Partial Least Square-Structural
Equation Modelling or PLS-SEM in the third objective. The PLS-SEM is an appropriate choice since the data was non-normal, and variables are reflective and formative in nature (Hair, Matthews, Matthews, \& Sarstedt, 2017; Hair, Ringle, \& Sarstedt, 2011).

It made used of hierarchical component modelling to reduce model complexity. In the first-order level, the 60 reflective indicators were checked whether or not they possess convergent and discriminant validity evidences, while in the second-order stage, each of formative indicators where those reflective indicators belong were also investigated. The research knowledge of participants was their summated scores in the test. In both components, the measurement and the structural equation models were assessed. This was carried out in WarpPLS 6.0 with Stable 3 as resampling and PLS regression and Warp3 as modelling algorithms (Kock, 2018).

The following hypotheses were tested.

Hypothesis 1: The individual (ind), institutional (ins), and/or leadership (lea) components are directly associated to research productivity $(R P)$.

Hypothesis 2: The leadership (Lea) component is directly associated to the institutional (ins) component.

Hypothesis 3: The leadership (Lea) and/or institutional (ins) components are directly associated to the individual (Ind) component.

The proposed model is shown in Figure 1.

\section{RESULTS}

\section{RP Outcomes of G10 Mathematics Teachers}

The RP index of the tenth-grade mathematics teachers is considered beginning, with weighted index of 0.57 , and highly skewed to the right. Of the 211 math teachers, only one of them had able to publish two of his researches. Four or 1.90 percent have other type of publications. Also, only 19 have research proposals and 19 have on-going or completed researches, majority of which were action researches. Majority of the papers' criterion variable is academic performance. Their initiatives target a better performance across mathematics competencies like in polynomials, word problem solving, inscribed and central angles, intersecting secants, and integers, among others. Some researchers evaluated students' performance in problem solving through Newman's Error Analysis and some devised interventions like using jigsaw model, tutorials, drills, differentiated instruction, team games tournament, lesson study, peer tutoring, and collaborative reading interventions to support at-risk students.

Approximately five of ten of the respondents have participated in at least one mathematics research-related trainings and workshops. These workshops include the 


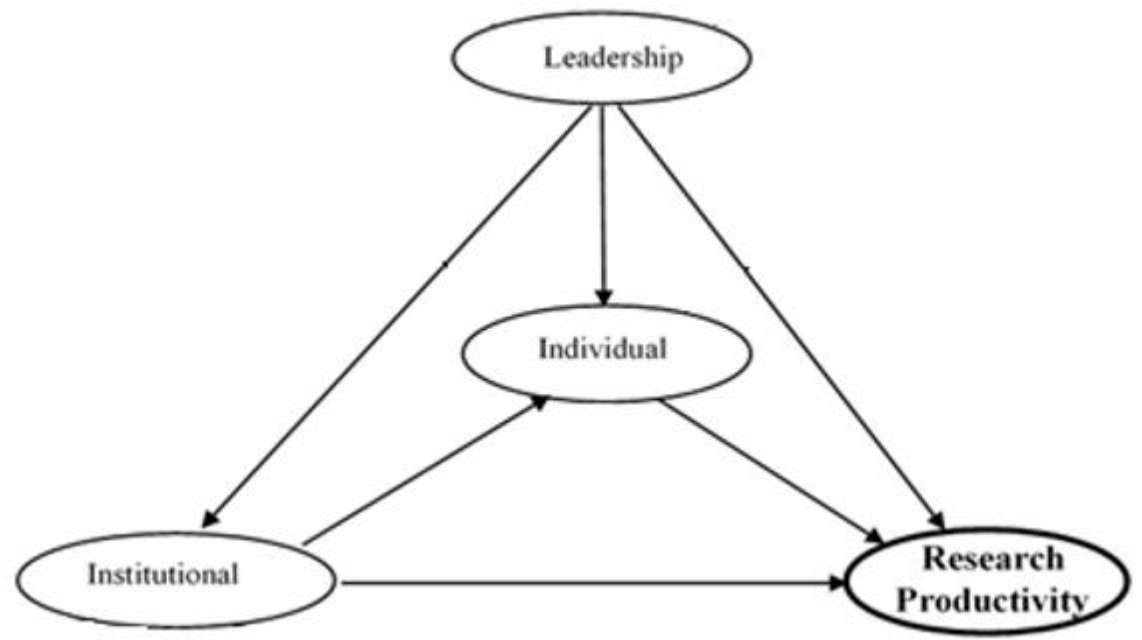

Figure 1. The Hypothesized Individual-Institutional-Leadership Model of Research Productivity

Regional Mass Trainings in Grade 10 and in senior high school which were cascaded down to teachers not accommodated in the major trainings. Seminarworkshops on localization, contextualization, spiral curriculum, calculus, and effective and contemporary strategies of teaching mathematics in the $21^{\text {st }}$ century was as well provided. Also, trainings on research, statistics, probability, quantitative and qualitative researches, basic education researches, and action researches were attended by the teachers. Ten were awarded with either mathematics- or research-related accolades. Only 35 of them engaged in research-related services as either one or more of the following: data analyst, language editor, and research adviser/consultant. Nine were affiliated in at least one of the two professional organizations.

\section{Enablers of RP}

Individual enablers of RP. The G10 math teachers' individual component was driving them towards RP $($ Mean $=3.76, \mathrm{SD}=0.95)$. Specifically, they had a decent internal driving force and confidence in research rationale $($ Mean $=4.07, \mathrm{SD}=1.05$ ). They reported fair amount of confidence in research results and work habits (Mean $=3.81, \mathrm{SD}=1.05$ ). The lower tier of means include writing of research reports based on national and international standards (Mean $=3.53, \mathrm{SD}=1.29)$ and more protected time for research (Mean $=3.61, \mathrm{SD}=$ 1.21). It was found out that the commitment on researchrelated activities is conditional on the intervening activities, and the commitment to research-related activities is derived from their wanting to have a better learning environment. Both are a function of time: one is a positive function of time, while the other is a negative function of time.

However, they feel less extrinsically motivated $($ Mean $=3.41, \mathrm{SD}=1.05)$. Their potentialities as teacherresearchers appeared to be shaken by their research knowledge $(\mathrm{MPS}=69.55, \mathrm{SD}=5.31$ ). Their highest performance is registered in the writing of related literature and studies followed by their performance in writing the problem and background of the study. Meanwhile, their lowest performances are in writing research titles, searching bibliography as well as research methodology. Technicalities of research shy them away from it.

Institutional enablers of RP. The schools can be a viable enabling environment where research can be nurtured $($ Mean $=3.52, \mathrm{SD}=1.03$ ). The pervading research goals in the institutions are understood by teachers $($ Mean $=4.11, \mathrm{SD}=1.27)$. Most schools have their school have school research committees (SRC) and research goals are circulated among teachers especially during meetings, Learning Action Cells (LAC) sessions, and trainings. Their SRC includes grammarian, statistician, research focal person, and the school head. They recanted nevertheless, that the level of articulating the research goals is insufficient.

Further, the potential areas that needs improvement are in research involvement, networking, and resources $($ Mean $=2.97, \mathrm{SD}=0.94)$ and in research mentoring (Mean $=3.49, \mathrm{SD}=1.36)$ because findings demonstrate that these two sub-areas were only to some extent enablers of RP. The respondents have not involved themselves in research-related tasks at least 12 hours weekly because of time constraints. The limited physical space, inadequate skills, low access to latest literature, and resources reduce their efficiency. Aside from personal laptops, the key informants vouched that their schools have internet connections. These assisted them in preparing their everyday lessons as well as their research-related tasks but they were limited to Google as the search engine. The data also exposed that their network is limited internally.

Leadership enablers of RP. The research leadership is slightly a driver of RP (Mean $=3.48, \mathrm{SD}=1.30)$. The strategic research leadership poses more concern (Mean $=3.37, \mathrm{SD}=1.33$ ) than the other subcomponent, since it 
is a degree lower than the incurred transformational and participative research leadership index (Mean $=3.59, \mathrm{SD}$ $=1.37$ ). The transformational research leadership in schools is slightly satisfactory in terms of championing research-related ideas of teachers, considering differences in needs and abilities in research, expressing enthusiasm that research goals will be achieved, and taking active interest and participation interest. In one end, they tend to feel that the research leaders themselves do not have research active careers, assistance is somewhat insufficient, information and updates on research management are somewhat lacking, and joint efforts towards funding, dissemination and utilization are slightly not within their reach.

With respect to strategic research leadership, the school vision for research goals is not yet in place due to the voluminous works they need to accomplish on top of their instructional functions.

\section{Structural Model of the Enablers of RP}

In the first-order validation, all reflective variables supported convergent validity having individual loadings of $.5, p<.05$, effect size $\left(\mathrm{f}^{2}\right)>.02$, Weight Loading Sign (WLS) = 1, except for RIN6 ("In my school, teaching takes away time from my research tasks."). There were no threats and significant cross loadings. Also, the composite reliabilities (CRs) were very high $(\mathrm{CR}>.90)$ and all Average Variance Extracted (AVEs) were above .50 .

To check the discriminant validity evidence, the Fornell-Larcker criterion disclosed concern for two pairs of LVs. StrLea and TraParLea had very close values of .939 and .867 and the square root of AVE of IntDriRat was less than the correlation between the LV and WorHabMetRes. The Full Collinearity Variance Inflation Factor (FCVIF) showed 5.104 and 5.468 for StrLea and TraParLea, respectively, which exceeded the conservative criterion of VIF of 3.3. The FCVIF of IntDriRat and WorHabMetRes were slightly lower than 3.3 as well. Hence, the pairs of StrLea and TraParLea, and IntDriRat and WorHabMetRes were judged as redundant. As a solution, these pairs were aggregated (Kock \& Lynn, 2012). The former was renamed leadership in research while the latter was renamed as intrinsic motivation, the original proposed construct of the researcher. Therefore, leadership (Lea) is a single and first-order construct similar to Angaiz's (2015). Then, the model was rerun.

The results of the Fornell-Larcker criterion this time provided discriminant validity evidence as diagonal elements are larger than the off-diagonal elements. The Heterotrait-Monotrait (HTMT) ratio of correlation specifically the $\mathrm{HTMT}_{85}, \mathrm{HTMT}_{90}$, and $\mathrm{HTMT}_{\text {inference }}$ in Smart PLS 3.0 (Ringle, Wende, \& Becker, 2015) also support claims on the discriminant validity of the LVs. The highest ratio in the $\mathrm{HTMT}_{90}$ was between leadership and involvement, network and resources, .649, way below the value and .85 or .90 cut-off. The HTMT inference also led to the rejection of the null hypothesis that the confidence interval contains one. There are no collinearity issues among LVs as depicted by the VIF values of less than 3.3 .

With respect to convergent validity of the secondorder validation of formative variables, all $p$-values were less than .05 and $\mathrm{f}^{2}>.02$ which denote that variable measurement items are properly constructed (Kock, 2018). All loadings are above the minimum (.2) which means they are significant formative indicators and the sign of the item weights was consistent with the underlying theory. Indicators within each of the LV as distinct and are not collinear with less than the VIF cap of 2.5 or 3.3. The WLS indices of positive one are making a statement that the Simpson's paradox instance does not exist in the measurement model. The variables are thus, positively contributing to the R-squared of the second-order LVs. The analysis supports an acceptable discriminant validity of the second-order LVs. The comparison between diagonal elements and values below and above them shows that the diagonal elements are larger than those values.

For the first hypothesis, the findings show that there is a significant direct link of Ind component to RP, $\beta=$ $.389, \mathrm{SE}=.064, p=.000$. The $f^{2}$ coefficient (.166) means that individual component is moderately relevant to RP. The Block VIF implies that Ind is a unique LV with respect to RP. Meanwhile, the Ins component has no significant direct influence to $\mathrm{RP}\left(\beta=.073, \mathrm{SE}=.068, f^{2}=\right.$ $.018, p=.142$, VIF < 3.3). The direct link between Lea component and RP is statistically not significant $(\beta=$ $.087, \mathrm{SE}=.068, p=.100, f^{2}=.018, \mathrm{VIF}<3.3$ ).

In the second hypothesis, the Lea component has a direct impact and very strong relevance to Ins component, $\beta=.820, \mathrm{SE}=.059, p=.000, f^{2}=.672$.

In the third hypothesis, the Lea component has no direct bearing to Ind component with path coefficient of $.019, \mathrm{SE}=.069, p>.05, f^{2}=.007$. Ins component directly and moderately affects Ind component $(\beta=.458, \mathrm{SE}=$ $.063, p=.000, f^{2}=.202$ ).

Figure 1 displays the structural model of the study.

The model fit indices provide an evidence that the structural model is well fit and highly acceptable. The APC, ARS, and AARS are significant having p-values equal to or lower than .05. AVIF and AFVIF tests also ensure that LVs are distinct because the values are lower than 3.3. The GoF index of .545 shows that the model has strong explanatory power. The SPR of one means that all paths are free from Simpson's paradox. Also, the RSCR of 1.000, which is greater than the minimum .9, divulges that the sum of the absolute $R$-squared contributions makes up all the $r$-squared contributions in the model. The SSR of 1.00 is very acceptable because it is greater than .7 and it means that all paths are free from statistical 


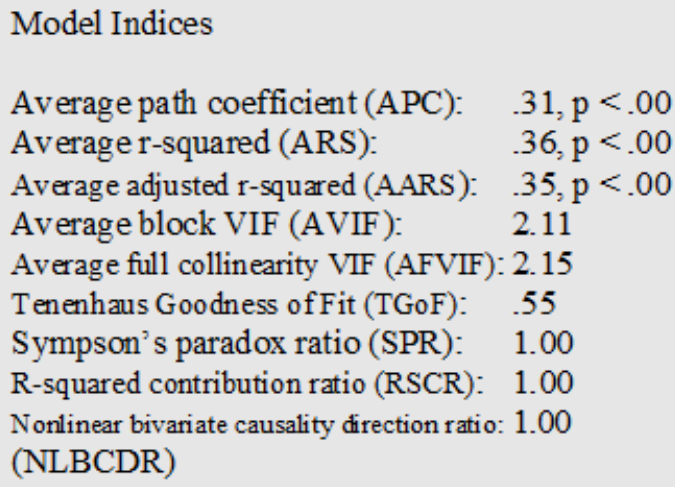

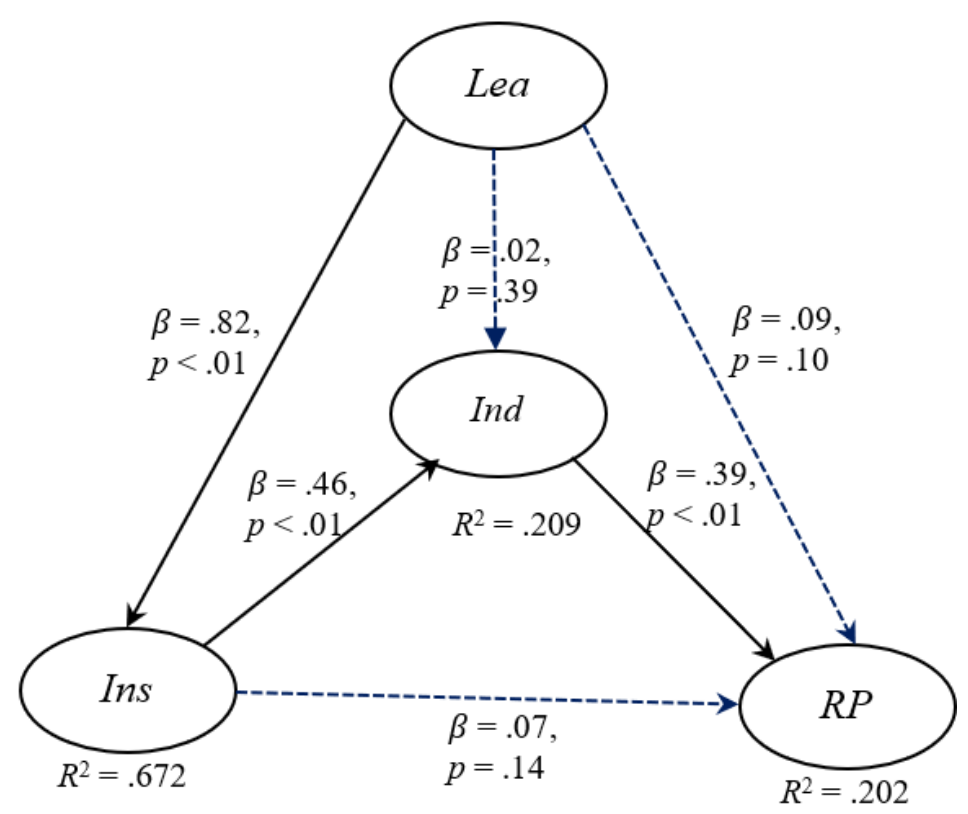

Dotted lines signify that the paths are not significant

Figure 2. The Results of the Hypothesized Individual-Institutional-Leadership Model of Research Productivity

suppression. The NLBCDR of .1 .00 supports all hypothesized directions of causality.

\section{DISCUSSION}

On the growing recognition of the potentials of research in educational settings and policy making in the basic education sector, it is important to find out whether a classroom teacher is geared towards a teacherresearcher genome. As shown, the mathematics high school teachers are beginning in terms of research productivity. Despite appreciation of what can research bring them in their duties and responsibilities, they are constricted of the idea that their major task is to teach rather than to research with little spare time to perform the latter. They find it difficult seeing themselves as data analysts and information processing individuals (Garcia, 2011). Ramos (2017) reported that in 2010-2014 only two of ten produced researches in their school, 90 percent of teachers were not skilled in research. Despite numerous attendances to capacity-building research-related programs, membership to professional organizations, and other professional development participation, teachers tend to be reluctant in documenting and reporting their academic efforts through a research paper like action researches. For instance, DepEd revealed during the 2018 Research Management Conference that there was an increased number of researches, but is still considered few in terms of the number of research proposals with respect to their population size, from 458 to 551 or 20.31 percent markup between 2016 and 2017, and a dip of 11.62 percent in 2017.

Among the key enablers, it was evident that the individual component is most decisive. The goal of becoming research productive originates within the mathematics teachers themselves who get the most out of their intrinsic motivation, extrinsic motivation, and knowledge in research. This agrees with most models of RP like those of Tafreshi et al. (2013), Hedjazi and Behravan (2011), Bland et al. (2005: 2002), Teodorescu (2000), and Dundar and Lewis (1998) that individual component has a direct link to RP. If one has a strong interest and desire in participating in research-related activities, the more likely that he/she becomes productive (Angaiz, 2015; Horodnic \& Zait, 2015; Nasser-Abu Alhija \& Majdob, 2017) especially when attached with extrinsic motivation (Hoffmann, Berg, \& Koufogiannakis, 2017; Tien \& Blackburn, 1996). The higher confidence a researcher possesses in terms of his ability to conduct research, the more likely he will be able to conduct one (Angaiz, 2015; Hoffman et al., 2017). A stronger commitment enables teachers to be responsive in their tasks of conducting research investigations (Hoffman et al., 2014, 2017). So, it leaves the question how does institutional and leadership impact RP and how those two interact with individual component towards RP?

Interestingly, institutional component does not directly impact RP. This is similar to Tafreshi et al.'s (2013) but counterintuitive with the results of Hedjazi and Behravan (2011), Hesli and Lee (2011), Duffy, Martin, Bryan, and Raque-Bogdan (2008), Bland et al. (2005), Bland et al. (2002), Teodorescu (2000), Dundar and Lewis (1998) as well as the local impact model of Marcial (2015) that institutional component has direct impact on RP. This can be logical at one point since the teachers are the prime movers; so any dynamics in education is incumbent upon the response of the teachers. An institution with established research goals, although it is essential cannot warrant Grade 10 math teachers to participate in research-related activities. In 
the same way, the presence or absence of resources could not directly ensure research outcomes (Abouchedid \& Abdelnour, 2015). They are helpful factors in RP (Gregorutti, 2008; Hedjazi \& Behravan, 2011), but it turned out to be negligible with respect to the participants of the study.

Similarly, a strong leadership in the research area is not synonymous with having research productive teachers. These results contradict the regression model of Santo et al. (2009) as well as of Paul et al. (2017), stating the defined direct contribution of leadership component to RP. Based on the presumption that research leaders handle the responsibility of monitoring research progress (Fetalver, 2010), the conjecture that poor research outputs obtain from inadequate leadership support (Ludovice-Yap \& Fajardo, 2007) or even its converse is thus, unacceptable. A similar opposing result is unravelled between this component and RP in relation to the foreign studies of Angaiz (2015), Ju (2010), Bland et al. (2005), Bland et al. (2002), Teoderescu (2000), and Dundar and Lewis (1998).

While there was no direct relationship of leadership in research and $\mathrm{RP}$, the leadership in research is nonetheless related to institutional attributes. It is an affirmation of the school research leaders' role in the institutions in shaping and promoting the organization (Nemaei, 2012). They develop policies in the institution that promote RP (Aithal, 2016) like on incentive systems (Cuntapay et al., 2014), networking (Bland et al., 2002), and securing research grants and resources (University of York, 2018). Leadership of research and development contributes to organizational performance (Wahab et al., 2016), innovativeness of academic staff (Elrehail, Emeagwali, Alsaad, \& Alzghoul, 2018) and academic productivity (McInnis et al., 2014). It is central to the development of successful research environments in the schools (Carlsson, Kettis, \& Soderlm, 2013). Visionary school research leaders are likely to demonstrate actions in their institutions like in the mentoring of potential research-driven teachers towards the achievement of the DepEd's research goals. Participative and transformational characteristics of school research leaders are reflected in the way they capacitate their colleagues, facilitate exchange of ideas, while maintaining a healthy relationship.

The nonexistence of a significant relationship of leadership in research and individual component is essentially conflicting with the views of classic models in RP like that of Bland et al's (2005). More specifically, this clashes with the inference that leadership in research influences the level of motivation and commitment to work (Franklin, 2016), stimulate teachers to participate in research (Sheldon et al., 2003), improve employees' creativity (Jantz, 2017), and enhances research capability of teachers (Cuntapay et al., 2014). This tends to warn school research leaders that their presence is not yet felt.
They have not yet established themselves as functional SRCs in the eyes of the teachers.

Meanwhile, Ins component directly and moderately affects Ind component. The system by which goals are articulated, mentoring are practiced, and involvement, network, and resources are presented in an institution pave the way to opportunities of growth on the knowledge in research, and the intrinsic and extrinsic motivation of the G10 mathematics teachers. Alternately, poor institutional support leads to research difficulties (Sharobeam \& Howard, 2002). Insufficiency of resources, networks, and involvement may demoralize teachers that leads to a low motivation, lower level of selfconfidence and commitment (Nguyen, 2015). Mentoring (Hafsteinsdóttir, van der Zwagg, \& Schuurmans, 2017) and resources (Acar, 2012) can improve knowledge in research. This result corroborates with the model of Williams (2003).

The model strongly suggests how leadership and institutional components can become indispensable to individual component towards research productivity. The motivation, commitment, and knowledge in research of teachers, in order to be converted as an actual research output, a strong institutional support must be in place. As this is the case, a good leadership in research must build a strong institutional support towards engagement of teachers in research-related activities.

More importantly, the commitment of teachers to research should yield better teaching in the long run. While it may be true that the connection of teaching and research is murky, number of authorities view the complementarity of research and teaching (Artes, Pedraja-Chaparro, \& Salinas-Jimenez, 2017; Pawar, 2015; Puustinen, Jaanti, Koski, \& Tammi, 2018; Rodriguez and Rubio, 2016). Continuing research in math is important because incredibly useful concepts have continue to come from mathematics and are helping people solve real-world problems, appreciate the ancient and collaborative art form, train people to think abstractly, and stimulate people for having a skeptical mindset (O'Neil, 2014).

\section{CONCLUSION/RECOMMENDATION}

Reflective teachers are effective teachers (Geldenhuys \& Oosthuizen, 2015). The tenth grade mathematics teachers are not yet considered research productive but there is an immense growth potential of becoming teacher-researchers. They understand that research is an integral part in carrying out their professional tasks but their indecision to participate emanates from multiple factors such imbalances in the areas of personal, institutional and leadership in research.

In spite of disequilibrium, the personal and institutional forces are generally promising but the leadership in research thriving in the school level poses imminent concerns. Hence, the joint enterprise of 
teachers, their respective institutions, and research leadership organically contribute towards research productivity with the teachers as the most critical element. Notably, the leadership in research component acts as the initial point towards the impact of institutional to personal component of RP. To catalyse $\mathrm{RP}$ among the teachers is to activate and sustain transformative and participative leadership in research channelled to as programs and initiatives in their respective institutions and divisions.

These findings have important policy implications regarding the improvement of teaching and learning in mathematics in the basic education. The complementary perspective of research and teaching is something that must be given due emphasis when planning for intervention activities. In developing professional development for teachers, a focus on teachers' reflective practices as classroom teachers and their capacity to translate it as research products as bases of curriculum policies and implementations are critically important. While there seems to be a duality in temporal perspective of the relationship of teacher and researcher, the math teachers as researchers instead of the math teachers-and/or-researchers is gaining larger attention in the countryside not only in the higher education but also in the basic education.

\section{LIMITATIONS}

The use of a self-reported cross-sectional data in RP instead of longitudinal measures may hardly establish a true causal relationship. To Pasupathy and Siwatu (2014), empirical measures are better than self-reported measures. Karakaya-Ozyer and Aksu-Dunya (2018) disclosed that good theoretical background of variables permits the use of SEM, but the relationship established from cross-sectional data can hardly claim causality (Thomas \& Harris, 2001). Also, no documentation or proof exists that would support or verify the researchrelated outcomes and performances of secondary mathematics teachers; so the concept of "good faith" is applied. Teachers may also find it difficult to fully account their RP outputs for the last three years. Direct relationships were only hypothesized and therefore, indirect and total effects may be considered.

According to Jung (2014), Carrlson, Kettis, and Soderholm (2013), and Davenport, Thomas, and Cantrell (2002), different disciplines have different norms and traditions. Also, Hughes (2004) foregrounded that to study the relationship between research and teaching is to consider contextual factors. The work was situated in Region 02 with the provinces of Isabela, Batanes, and Quirino participating. Extensions to the work in other jurisdictions are highly encouraged.

\section{REFERENCES}

Abouchedid, K., \& Abdelnour, G. (2015). Faculty research productivity in six Arab countries. International Review of Education, 61(5), 673-690. https:/ / doi.org/10.1007/s11159-015-9518-5

Acar, B. C. (2012). Research capability of the selected public and private higher education institutions in Cebu City, Philippines. IAMURE International Journal of Education, 4, 58-101. https://doi.org/ 10.7718/iamure.ije.v4i1.449

Adler, J. (1997). Professionalism in process: Mathematics teacher as researcher from a South African perspective. Educational Action Research, 5(1), $87-$ 103. https:// doi.org/10.1080/09650799700200016

Afify, M. (2008). Action research: Solving real-world problems. Tourism and Hospitality Research, 8(2), 153-159. https:/ / doi.org/10.1057/thr.2008.13

Aithal, P. S. (2016). How to increase research productivity in higher educational institutions SIMS Model. International Journal of Scientific Research and Modern Education, 1(1), 447-458.

Angaiz, D. (2015). An investigation of determinants of teacher education faculty research productivity in public sector universities of Pakistan (Order No. 3664148). Available from ProQuest Dissertations \& Theses Global. (1727735265).

Artes, J., Pedraja-Chaparro, F., \& Jimenez, M. D. (2017). Research performance and teaching quality in the Spanish higher education system: evidence from a medium-sized university. Research Policy, 46, 19-29. https:/ / doi.org/10.1016/j.respol.2016.10.003

Blackburn, T., \& Lawrence, H. (1995). Faculty at work: Motivation, expectation, satisfaction. London: The Johns Hopkins University Press.

Bland, C. J., Center, B. A., Finstad, D. A., Risbey, K. R., \& Staples, J. (2006). The impact of appointment type on the productivity and commitment of full-time faculty in research and doctoral institutions. The Journal of Higher Education, 77(1). https:/ / doi.org/ 10.1353/jhe.2006.0002

Bland, C. J., Seaquist, E., Pacala, J. T., Center, B., \& Finstad, D. (2002). One school's strategy to assess and improve the vitality of its faculty. Academic Medicine, 77(5), 368-376. https://doi.org/10.1097/ 00001888-200205000-00004

Bland, C. J., Weber-Main, A. M., Lund, S. M., \& Finstad, D. A. (2005). The research productive departments: Strategies from departments that excel. New York: Anker Publishing Company.

Bonner, P. J. (2006). Transformation of teacher attitude and approach to math instruction through collaborative action research. Teacher Education Quarterly, 33(3). 
Brocato, J. J. (2001). The research productivity of family medicine department faculty: A national study. Michigan State University, Department of Educational Administration, U.S.

Cabaroglu, N. (2014). Professional development through action research: Impact on self-efficacy. System, 44, 79-88. https://doi.org/10.1016/j.system.2014.03. 003

Carlsson, H., Kettis, A., \& Soderholm, A. (2013). Research quality and the role of the university leadership, 1-48. Stockholm, Sweden: The Swedish Association of Higher Education (SUHF)/ Experts' Committee on Quality.

Chant, R., Heafner, T., \& Bennett, K. (2004). Connecting personal theorizing and action research in preservice teacher development. Teacher Education Quarterly, 31(3), 25-42.

Chapman, O. (2017). Understanding and enhancing teachers' knowledge for teaching mathematics. Journal of Math Teacher Education, 20, 203-205. https:/ / doi.org/10.1007/s10857-017-9372-4

Craig, C. J. (2009). Teacher research and teacher as researcher. International Handbook of research on Teachers and Teaching, 61-70. https:/ / doi.org/10.1007/9780-387-73317-3_4

Cuntapay, M. C., Garay, G. \& Viloria, P. F. (2014). Needs assessment of teacher's research capability. College of Arts and Sciences Research Journal, 5 (1).

Dangan, S. D. (2014). Gender, rank, and teaching hours as predictors of research productivity among higher education faculty. IAMURE International Journal of Multidisciplinary Research, 11(1). https://doi.org/10.7718/iamure.v11i1.863

Davenport, T. H., Thomas, R. J., \& Cantrell, S. (2002). The mysterious art and science of knowledge-worker performance. Sloan Management Review (Fall), 23-30.

Demski, J. S., \& Zimmerman, J. L. (2000). On research vs. teaching: A long-term perspective. Accounting Horizons, 14(3), 343-352. https://doi.org/10.2308/ acch.2000.14.3.343

DepEd Order No. 13, s. 2015. Establishment of a policy development process at the Department of Education. Pasig City, Philippines.

DepEd Order No. 16, s. 2017. Research management guidelines. Pasig City, Philippines.

DepEd Order No. 39, s. 2016. Adoption of the basic education research agenda. Pasig City, Philippines.

DepEd Order No. 4, s. 2016. Amendment to DepEd Order No. 43, s. 2015. Pasig City, Philippines.

DepEd Order No. 43, s. 2015. Revised guidelines for the basic education research fund (BERF). Pasig City, Philippines.

Duffy, R. D., Martin, H. M., Bryan, N. A., \& RaqueBogdan, T. L. (2008). Measuring individual research productivity: a review and development of the integrated research productivity index. Journal of Counselling Psychology, 55(4), 518-527. https:/ / doi.org/10.1037/a0013618

Dullas, L. D. (2018). Competencies and outcomes in quantitative research writing among junior high school mathematics teachers (Unpublished Dissertation). Saint Mary's University, Bayombong, Nueva Vizcaya, Philippines.

Dumbrique, J. S., \& Alon, T. D. (2013). Research productivity of business administration and accountancy faculty, University of Northern Philippines, Vigan City. IAMURE International Journal of Education, 6(1). https:/ / doi.org/10.7718/iamure.ije.v6i1.502

Dundar, H., \& Lewis, D. (1998). Determinants of research productivity in higher education. Research in Higher Education, 39 (6), 607-631. https:/ / doi.org/10.1023/ A:1018705823763

Elrehail, H., Emeagwali, O. L., Alsaad, A., \& Alzghoul, A. (2018). The impact of transformational and authentic leadership on innovation on higher education: The contingent role of knowledge sharing. Telematics and Informatics, 35, 55-67. https://doi.org/10.1016/j.tele.2017.09.018

Etcuban, J. O., Andrin, G., R., Ninal, M., Campanilla, B. S., Dinauanao, A. M., Macugay, P. J. D. R., \& Belarmino, G. A. (2016). Research productivity among faculty members of the University of Cebu, Philippines. JPAIR Institutional Research, 8(1)-20-40. https:/ / doi.org/10.7719/irj.v8i1.422

Evitts, T. (2004). Action research: a tool for exploring change. The Mathematics Teacher, 97(5), 366-370.

Feamster, N. (2013, November 1). The relationship between teaching and research. Retrieved from https:/ / greatresearch.org/2013/11/01/therelationship-between-teaching-and-research/

Fetalver, Jr, M. A. (2010). Predictors of Research Dissemination and Utilization in State Higher Education Institutions in Region IV, Philippines. Liceo Journal of Higher Education Research, 6(2). https:/ / doi.org/10.7828/ljher.v6i2.79

Franklin, K. (2016). Examining the impact of leadership styles on the motivation of US Teachers (Dissertation). Retrieved from https://pdfs.semanticscholar.org/ bb21/788d6ee8ec8854254bc6d0d2307fd0519443.pd

Garcia, A. G. (2011). Teachers conducting research: from apprehension to fearless! International Journal of University Teaching and Faculty Development, 2(4), 245-262.

Goodall, A. H., McDowell, J. M. \& Singell, L. D. (2014). Leadership and the research productivity of university departments (Discussion Paper). Retrieved from 
Gregorutti, G. (2008). A mixed method study of the environment and personal factors that influence research productivity at small-medium, private, doctorategranting universities. 3306671 Andrews University, Ann Arbor.

Hafsteinsdóttir, T. B., Van der Zwagg, A. M., \& Schuurmans, M. J. (2017). Leadership mentoring in nursing research, career development and scholarly productivity: A symmetric review. International Journal of Nursing Studies, 75, 21-34. https:/ / doi.org/10.1016/j.ijnurstu.2017.07.004

Hair, J. F., Ringle, C. M., \& Sarstedt, M. (2011). PLS-SEM: indeed a silver bullet. Journal of Marketing Theory and Practice, 19 (2), 139-150. https://doi.org/ 10.2753/MTP1069-6679190202

Hair,J. F. Jr., Matthews, L. M., Matthews, R. L., \& Sarsdtedt, M. (2017). PLS-SEM or CB-SEM: updated guidelines on which method to use. International Journal of Multivariate Data Analysis, 1(2), 107-123. https:/ / doi.org/10.1504/IJMDA.2017.087624

Hedjazi, Y., \& Behravan, J. (2011). Study of factors influencing research productivity of agriculture faculty members in Iran. Higher Education, 62 (5), 635-647. https://doi.org/10.1007/s10734-0119410-6

Hesli, V., \& Lee, J. (2011). Faculty research productivity: Why do some of our colleagues publish more than others? PS: Political Science and Politics, 44(2), 393408. https:/ / doi.org/10.1017/S1049096511000242

Hoffmann, K., Berg, S., \& Koufogiannakis, D. (2014). Examining success: Identifying factors that contribute to research productivity across librarianship and other disciplines. Western Librarian Publications, 38(119), 12-28. https:/ / doi.org/10.29173/lirg639

Hoffmann, K., Berg, S., \& Koufogiannakis, D. (2017). Understanding factors that encourage research productivity for academic librarians. Evidence Based Library and Information Practice, 12(4), 102-128. https:/ / doi.org/10.18438/B8G66F

Horodnic, I. A., \& Zait, A. (2015). Motivation and research productivity in a university system undergoing transition, Research Evaluation, 24(3), 282-292. https:/ / doi.org/10.1093/reseval/rvv010

Hughes, M. (2004). The relations between research and teaching in higher education- a review of the literature (1990-2002). Retrieved from http://citeseerx.ist. psu.edu/viewdoc/download?doi=10.1.1.201.6980 \&rep=rep $1 \&$ type $=$ pdf

Jalloun, O. A. (2010). Faculty research socialization: A study of faculty perceptions of research socialization experiences at a large research university (Order No. 3447313). Available from ProQuest Dissertations \& Theses Global. (862744768).
Jantz, R. (2017). Vision, innovation, and leadership in research libraries. Library and Information Science Research, 39, 234-241. https://doi.org/10.1016/ j.lisr.2017.07.006

Ju, M. (2010). The impact of institutional and peer support on faculty research productivity: A comparative analysis of research vs. non-research institutions (Order No. 3428719). Available from ProQuest Dissertations \& Theses Global. (759116154).

Jung, J. (2014). Research productivity by career stage among Korean academics. Tertiary Education and Management, 20(2), 85-105. https://doi.org/ $10.1080 / 13583883.2014 .889206$

Käpylä, J., Jääskeläinen, A., \& Lönnqvist, A. (2010). Identifying future challenges for productivity research: Evidence from Finland. International Journal of Productivity and Performance Management, 59(7), 607-623. https://doi.org/10.1108/ 17410401011075620

Karakaya-Ozyer, K., \& Aksu-Dunya, B. (2018). A review of structural equation modeling applications in Turkish educational science literature, 2010-2015. https://doi.org/10.21890/ijres.383177

Kock, N. (2018). WarpPLS user manual: Version 6.0. Laredo, TX: ScriptWarp Systems.

Kock, N., \& Lynn, G. S. (2012). Lateral collinearity and misleading results in variance-based SEM: An illustration and recommendations. Journal of the Association for Information Systems, 13(7), 546-580. https:/ / doi.org/10.17705/1jais.00302

Koo, T. K., \& Li, M. Y. (2016). A guideline of selecting and reporting intraclass correlation coefficients for reliability research. Journal of Chiropractic Medicine, 15, 155-163. https:/ / doi.org/10.1016/j.jcm.2016.02. 012

Linacre, J. M. (2011). A user's guide to WINSTEPS and MINISTEP: Rasch-model computer programs. Program manual 3.72.0. Chicago, IL: Winsteps.com.

Ludovice-Yap, T. S., \& Fajardo, T. Q. (2007). Attitudinal patterns on research of faculty members of the UERMMMC college of medicine. UERMMMC Journal of Health Sciences, 10(1).

Magidson, S. (2005). Building bridges within mathematics education: Teaching, research, and instructional design. Journal of Mathematical Behavior, 24, 135-169. https://doi.org/10.1016/ j.jmathb.2005.03.004

Marcial, V. G. (2015). Development of an impact paradigm for institutional research productivity. Asia Pacific Journal of Multidisciplinary Research, 3(5), 80-93.

Marsh, H., \& Hattie, J. (2002). The relation between research productivity and teaching effectiveness: Complementary, antagonistic, or independent 
constructs? The Journal of Higher Education, 73(5), 603-641. https:/ / doi.org/10.1353/jhe.2002.0047

McInnis, C., Ramsden, P., \& Maconachie, D. (2014). A handbook for executive leadership of research development. Centre for Leadership in Research Development, University of the Sunshine Coast (USC).

Montes, L. J. F., Moreno, R. A., \& Morales, G. V. (2005). Influence of support leadership and teamwork cohesion on organizational learning, innovation and performance: An empirical examination. Technovation, 25, 1159-1172. https://doi.org/ 10.1016/j.technovation.2004.05.002

Nasser-Abu Alhija, F. M., \& Majdob, A. (2017). Predictors of teacher educators' research productivity. Australian Journal of Teacher Education, 42(11).https:/ / doi.org/10.14221/ajte.2017v42n11.3

Nemaei, B. (2012). The impact of participative leadership on employee's motivation, job satisfaction and innovation (Unpublished Dissertation). Retrieved from https://bspace.buid.ac.ae/bitstream/1234/343/1 /80080.pdf

Nguyen, Q. H. (2015). Factors influencing the research productivity of academics at the research-oriented university in Vietnam. Retrieved from https://research-repository.griffith.edu.au/ bitstream/handle/10072/366248/Nguyen_2015_0 2Thesis.pdf? sequence $=1 \&$ is Allowed $=y$

Nuqui, A. V., \& Cruz, R. C. (2012). Determinants of faculty research productivity in Augustinian higher education institutions in Luzon. IAMURE International Journal of Education, 3(1), 56-74. https:// doi.org/10.7718/iamure.ije.v3i1.191

O'Neil, C. (2014, February 13). Why is math research important? (Web blog). Retrieved from https://goo.gl/y34v58

Pasupathy, R., \& Siwatu, K. O. (2014) An investigation of research self-efficacy beliefs and research productivity among faculty members at an emerging research university in the USA, Higher Education Research \& Development, 33(4), 728-741. https:/ / doi.org/10.1080/07294360.2013.863843

Paul, S., Vijayaragavan K., Singh, P. S., Burmal, R. R., \& Chahal, V. P. (2017). Determinants of research productivity of agricultural scientists: Implications for the national agricultural research and education system of India. Current Science, 112(2), 252-257. https://doi.org/10.18520/cs/v112/i02/252-257

Pawar, B. S. (2015). Enhancing research-teaching link in organizational behavioral: Illustration through an actual example. The International Journal of Management Education, 13, 326-336. https:// doi.org/10.1016/j.ijme.2015.10.005

Polit, D. D., Beck, C. T., \& Owen, S. V. (2007). Is the CVI an acceptable indicator of content validity?
Appraisal and recommendations. Research in Nursing $\mathcal{E}$ Health, 30, 459-467. https://doi.org/ 10.1002/nur.20199

Polit, D. F., \& Beck, C. T. (2006). The content validity index: Are you sure you know what's being reported: critique and recommendations. Research in Nursing \& Health, 29, 489-497. https:/ / doi.org/ 10.1002/nur.20147

Prince, M. J., Felder, R. M., \& Brent, R. (2007). Does faculty research improve undergraduate teaching? An analysis of existing and potential synergies. Journal of Engineering Education, 96(4), 283-294. https: // doi.org/10.1002/j.2168-9830.2007.tb00939.x

Puustinen, M., Santti, J., Koski, A., \& Tammi, T. (2018). Teaching: A practical or research-based profession? Teacher candidates' approaches to research-based teacher education. Teaching and Teacher Education, 74, 170-179. https:/ / doi.org/10.1016/j.tate.2018.05. 004

Quimbo, M. A. T., \& Sulabo, E. C. (2014). Research productivity and its policy implications in higher education institutions. Studies in Higher Education, 39(10), 1955-1971. https://doi.org/10.1080/ 03075079.2013.818639

Revilla, R. D., \& Ladisla, R. D. (2014). Letting the culture grow: constructing the research motivators among private HEIs in CALABARZON RegionPhilippines. IAMURE International Journal of Education, 11(1). https://doi.org/10.7718/iamure. ije.v11i1.911

Ringle, C. M., Wende, S., \& Becker, J.-M. (2015). SmartPLS 3. Boenningstedt: SmartPLS GmbH.

Rodriguez, R., \& Rubio, G. (2016). Teaching quality and academic research. International Review of Economics Education, 23, 10-27. https://doi.org/10.1016/ j.iree.2016.06.003

Santo, S. A., Engstrom, M. E., Reetz, L., Schweinle, W. E., \& Reed, K. (2009). Faculty productivity barriers and supports at a school of education. Innovative Higher Education, 34(2), 117-129. https:/ / doi.org/10.1007/ s10755-009-9098-Z

Segal, S. U. (2009). Action research in mathematics education: A study of a master's program for teachers TEACHERS (Dissertation). Retrieved from https://goo.gl/3DiTRr

Sharobeam, M., \& Howard, K. (2002). Teaching demands versus research productivity: Faculty workload in predominantly undergraduate institutions. Journal of College Science Teaching, 31(7), 436-441.

Siegel, D., Waldman, D., \& Link, A. (2003). Assessing the impact of organizational practices on the relative productivity of university technology transfer offices: An exploratory study. Research Policy, 32(1), 27-48. https://doi.org/10.1016/S0048-7333(01) 00196-2 
Tafreshi, G. H., Imani, M. N., \& Grashlag, P. M. (2013). Designing a model for research productivity evaluation of faculty of district 2 of Islamic Azad University of Iran. World Applied Sciences Journal, 21(12), 1708-1720.

Tagaro, C. A. (2015). Research culture and productivity of the faculty of accredited private higher education institutions. IAMURE International Journal of Education, 15(1). https://doi.org/10.7718/iamure. ije.v15i1.1057

Teodorescu, D. (2000). Correlates of faculty: A crossnational analysis of higher education and Islamic Azad University. Higher Education, 39, 201-222. https:/ / doi.org/10.1023/A:1003901018634

Thomas, R., \& Harris, V. (2001). Exploring connections between teaching and research in hospitality management. International Journal of Hospitality Management, 20, 245-257. https:/ / doi.org/10.1016/ S0278-4319(01)00008-1

Tien, F., \& Blackburn, R. (1996). Faculty rank system, research motivation, and faculty research productivity: measure refinement and theory testing. The Journal of Higher Education, 67(1), 2-22. https: / / doi.org/10.2307/2943901

Ulla, M. B. (2018). Benefits and challenges of doing research: Experiences from Philippine public school teachers. Issues in Educational Research, 28(3), 797-810.

Ulla, M. B., Barrera, K. I. B., \& Acompanado, M. M. (2017). Philippine classroom teachers as researches:
Teachers' perceptions, motivations, and challenges. Australian Journal of Teacher Education, 42(11), 52-64. https:/ / doi.org/10.14221/ajte.2017v42n11.4

uz Zaman, M. Q. (2004). Review of the academic evidence on the relationship between teaching and research in higher education. Department for Education and Skills London.

Valdez, P. N., \& Lapinid, M. R. (2015). Constraints of math teachers in conducting action research in the Philippines: Rights analysis. Malaysian Journal of Learning and Instruction, 12, 1-19. https:/ / doi.org/10.32890/mjli2015.12.1

Wahab, S., Rahmat, A., Yusof, M. S., \& Mohamed, B. (2016). Organization performance and leadership style: Issues in education service. Procedia and Educational Sciences, 224, 593-598. https://doi.org/ 10.1016/j.sbspro.2016.05.447

Williams, H. A. (2003). A mediated hierarchical regression analysis of factors related to research productivity of human resource education and workforce development postsecondary faculty (Order No. 3085705). Available from ProQuest Dissertations \& Theses Global. (305320869).

Zamarripa, E. J. (1995). Evaluating research productivity. SRA Journal, 26(3).

Zuljan, M. V., \& Vogrinc, J. (Ed.). (2010). Facilitating effective student learning through teacher research and innovation. Retrieved from https://www.pef.unilj.si/fileadmin/Datoteke/Zalozba/pdf/Zuljan_Vo grinc_Facilitating.pdf

\section{http://www.ejmste.com}

